\title{
INCOME INEQUALITIES IN EU COUNTRIES: GINI INDICATOR ANALYSIS
}

\author{
Mythili Kolluru $^{1}$, Tetiana Semenenko²
}

date of paper receipt:

20.03.2021.

Original Article date of sending to review:

22.03.2021.

doi: 10.2478/eoik-2021-0007 UDK 512.56+517.7]:330.85(4-672EU) date of review receipt:

06.04.2021.

${ }^{1}$ Professional Studies and Undergraduate Dept., College of Banking and Financial Studies; Muscat, Oman, e-mail: mythili@cbfs.edu.om

${ }^{2}$ Sumy State University, Ukraine, e-mail: t.semenenko@uabs.sumdu.edu.ua

\begin{abstract}
Franklin Delano Roosevelt said that "the test of our progress is not whether we add more to the abundance of those who have much; it is whether we provide enough for those who have too little." According to the World Economic Forum (2021), income disparity is at the top of global risks in the coming years. The development of income inequality is a growing concern worldwide, particularly since the Great Recession. This study is based on available data on the Gini coefficient of equivalized disposable income from 2005 to 2019 for the 27 European Union countries. We found that the indicator's value demonstrates a reasonably even distribution of income (not exceeding $40 \%)$ in all European Union countries, except Bulgaria. We used the FORECAST ETS function (Excel for Microsoft 365) that is based on the AAA version of the Exponential Smoothing (ETS) algorithm to conduct our analysis. We grouped the EU 27 countries to investigate income equality behavior. According to the interval's median of the sample's standard deviation, we selected Italy, Spain, Germany, Slovakia, Hungary, Bulgaria for further investigation. We conclude the absence of general trends in the inequality of income distribution in society due to the financial crisis factors. The research presents exploratory insights into income inequality in the European Union.
\end{abstract}

\section{Keywords:}

EU; Income inequality; Gini; Sturges formula; quintile; forecast; Exponential Smoothing; Global financial crisis; Standard deviation 


\section{INTRODUCTION}

The European Union (EU) is a novel economic and political union among 27 countries. It is a voluntary arrangement in which control rests with the separate member States who can, if they wish so, decide to leave the Union as the UK did on $31^{\text {st }}$ January 2020. More than 340 million EU citizens in 19 countries now use it as their currency and enjoy its benefits. Checchi et al. (2015) states that the EU is the largest economy globally, with a GDP per head of $€ 25,000$ for its 500 million consumers. With time European Union has acquired many attributes of a state, and, in economic terms, it can be considered a single market. Nonetheless, the differences between member states are enormous. Income inequality is a natural result of the individual and economic performance of individuals. Individual heterogeneity in talent and effort will result in different income results and consequently in a certain level of overall inequality. Income inequality is a factor that influences economic growth and development. It may result in higher taxes, political conflict, lower capital accumulation. Both scholars and government administrators are concerned about the evolution and negative impact of inequality on growth and development. Inequality has never been easy to measure. There are many problems when measuring and comparing income levels. There are aspects like income and expenditure, income before and after redistribution, the effect of owner occupancy and household production, and other various elements. Further, the different aspects that need to be considered are exchange rates and purchasing power, inflation rates, and considerable differences in national statistics. According to OECD (2021), the Gini coefficient is regularly used as a measure of inequality of income, consumption, or wealth. The Gini coefficient is based on comparing cumulative proportions of the population against cumulative proportions of income they receive. It ranges between 0 and 1 , in the case of perfect equality value is 0 and in the case of perfect inequality, value equals 1 .

The development of income inequality in the EU member states is a growing concern for the European region. There seems to be a general trend of widening the income gap starting in the 1980s CSRI (2017). There is a significant increase in income inequality of former 'equal societies', such as the Nordic countries and Germany. In general, there seems to be a convergence trend towards a generally higher level of income inequality. The 2007-2009 Great Recession more frequently known as the Global Financial Crisis had a significant negative impact on economic and household income growth in the EU. Still, the effect was more marked in some countries like the Baltic, and Southern European regions, leading to more significant divergence across and within countries. Growth resumed in all EU countries by 2014, some of the crisis-induced variations between countries have been reverted, and convergence remains hampered. As a result, EU-wide inequality increased in the aftermath of the crisis. Reducing inequality is an official aim of the European Union. It is a primary goal of their strategic plan. Ferrer (2005) describes that income equality is also worth achieving because greater equality is likely to increase the overall welfare of society. Understanding and measuring income inequality is significant. Frey and Stutzer (2002) portrays a picture of the income inequality in any region empowers the authorities to make better-informed decisions. EU has witnessed many dynamic changes on the political and economic front and yet they are the most competitive regions of the world. Checchi et.al, (2010) states that Over the past decade, economic unification has slowed down, giving birth to concerns over income inequality and social separation. Growth in household incomes and conjunction across countries until 2008 has been followed by years of crisis and stagnation, leading to attention over continued growth and integrity in the EU. The recession has impacted communities, but the impact has touched lives equally. Recent literature by Piketty (2013) has stimulated a fierce debate on inequality among academics and policymakers. Our research analyzing the Gini coefficient of equivalised disposable income from 2005 to 2019 for the EU 27 countries. We explored the Gini behavior during the Global Financial Crisis period to find out if there are general trends in the equality of income distribution associated with the 
crisis. Based on the sample standard deviation, we grouped the EU 27 countries by homogeneity to further explore income equality behavior. According to the criterion of the median, standard deviation of the sample, we selected one country in each group. As a result, we got a shortlist of countries for further research (Italy, Spain, Germany, Slovakia, Hungary, Bulgaria). We conclude the absence of general trends in changes in the inequality of income distribution in society as a reaction to the factors of the financial crisis. We limited the calculation of forecast values to three periods, including 2020.

\section{LITERATURE REVIEW}

The economic integration and unification of countries of the European Union have concerns over income inequality for the past decades. When you look at the EU as a single country, the income inequalities have declined over the years, but the income disparity between the rich and emerging countries is still vast. The present literature review is conducted to gauge the various studies on income inequalities across the European region.

Alfani (2019) the findings of this article show that inequality has been growing over the centuries. The authors describe how inequality is perceived in the modern world. Some causal factors are like demographic, social-economic, and institutional are explored to shed more light on the cause of inequality. Heiko (2017) discusses the hot topic of income inequality. In many countries where economic growth is sluggish, and unemployment is high, income inequality is debated in political circles. The article discusses the drivers of income inequality as globalization, technological change, and migration. Over the years, various scholars have studied the relationships between income inequality and important social outcome variables. Giorgi (1990) states that the Gini is a wellstudied index with a long history and is associated with the area between equality and the Lorenz curve. The Italian statistician Corrado Gini devised this statistical tool in the year 1912. It is a popular measure of socioeconomic inequality, especially in income and wealth distribution. Gini (2005) states that the Gini index can be calculated as the area between the perfect equality line and the Lorenz curve divided by the total area under the ideal equality line. The Gini index takes values in the unit interval. The closer the index is to zero, the equal income distribution. The closer the index is to one (where the area A is large), the more unequal the income distribution. Gastwirth (1972) provides a graphical summary of the distribution, which economists and policymakers use. The studies of Wilkinson and Pickett (2009), Atkinson (2013), and Piketty (2020) show that higher inequality leads to adverse socio-economic outcomes in advanced economies. According to Eliazar (2012), the Gini index application has crossed socioeconomic scope and entered various science disciplines. Another study by Elizar (2018) states that the Gini index applies to any size distributions in the context of available data sets with non-negative quantities such as count, length, area, volume, mass, energy, and duration. The panel data analysis of the Gini coefficient by Fajnzylber et al. (2002a) shows that inequality increases homicide and robbery rates. In another study, Fajnzylber et al. (2002b) also conclude that crime rates and inequality are positively correlated. Alesina and La Ferrara's (2002) investigations on the Gini for a metropolitan region show that respondents living in more fragmented, and income unequal communities report lower trust levels. Another interesting study is done by Knack and Keefer (1997). Their work demonstrates that trust and civic norms are more robust in nations with higher and more equal incomes. The result of Perotti (1993) links society to education. He states that an equal society has higher rates of investment in education. Checchi (2003) studies the relationship between the Gini and school enrollment rates. He looks at 108 countries to confirm the negative correlation between income inequality and secondary enrollment; he further claims that income inequality has a more substantial effect on women's primary and tertiary education enrollment. Solt (2008) brings out the relationship between income inequality and citizens' political involvement. His study on 23 advanced countries from 1984 to 2000 reveals that the country's income inequality reduces individual political engagement. The effect increases with relative declining income. Schwarze \& Harpfer (2007) studied the negative effect of income inequality on life satisfaction in Germany. They found that it did had an impact on 
life satisfaction but influenced the relative income position of people. They used the Gini coefficient for their study. Senik (2004) used the Gini with Ordered probit on a study of Russian individuals and concluded that inequality indices do not affect individual satisfaction. The reviews of Sanfey and Teksoz (2005) show that inequality harms life satisfaction across multiple transition countries. Several studies have analyzed the relationship between income inequality and life satisfaction in various transition countries.

The global concern for income inequality has increased further since the start of the Global Recession. The studies of Krugman (2008) have shown the role of inequality in the growth process and stated that the evolution of inequality is the leading cause and natural consequence of the Great Recession. The studies of Stiglitz (2009) and Rajan's (2010) findings are in line with Krugman's results. Patridge (2005) for the USA, Rodríguez, and Tselios (2008) for Europe, and Castells and Royuela et al. (2014b) for the OECD have studied the relationship between Gini Index and GDP per capita over several years. Their findings demonstrate that, on average, more developed countries have lower inequality levels. It is fair to think that Europe is already a developed region in the world. But other scholars demonstrate the negative association of the Gini Index and economic development. Some models of 1996 and 2000 have proved that higher inequality in more developed regions can be linked to the idea of evolution through innovations associated with increasing inequalities. Therefore, it shows that the sectoral composition of the economy matters. The work of Castells and Royuela (2014a) states that inequality can be associated with agglomeration economies and the spatial concentration of resources, which circumstances can be a positive factor for economic development. Blanchet et al. (2019) bought together all existing sources on income inequality in Europe since 1980 to produce national distributional accounts. He further comments on inequality since the 1980s, and notes that there has been an increase in income disparities. The researchers Dorwick and Akmal (2005), Milanovic (2002) and Sala-i-Martín (2006), Brandolini (2007), Barro (2020), Dauderstädt (2008), and Franzini (2009) have explicitly covered European income inequality. However, according to Anand and Segal (2008), these approaches have many limitations. They are also subject to academic criticism. Inequality is difficult to measure, but measuring transnational inequality is especially difficult. Constructing a measure of international income inequality is no simple mathematical operation. The Gini and the Theil T-index and income brackets, such as deciles or quintiles, are common measures of inequality. In economic terms, European Union is considered as a single market and has over the years developed the attributes of a single state. Nonetheless, the differences between member states are enormous. Small, rich countries, such as Luxembourg, contrast sharply with big, poor ones, such as Romania.

The literature review substantially demonstrates that the Gini coefficient is a widely used and accepted measure for income inequality. There are many scholarly contributions to the Gini coefficient and European studies. There is a scope for adding to the available body of knowledge, especially since the world is facing declined economic growth with the pandemic's advent. Our research attempts to add an iota of knowledge to understanding the income inequality in EU-27. Our research work has four aims: First, to analyze the Gini coefficient for EU countries from 20052019, to highlight the trends in income distribution inequality during the Global Financial crisis of 2008-2009. Second, examine if the extremes (minimum and maximum values) are consistent with the corresponding response of the S80/S20 disposable income quintile share ratio. Third, to give a forecast estimate of the Gini coefficient for future periods.

\section{METHODOLOGY}

The presented study is based on available data on the Gini coefficient of equivalized disposable income for the period from 2005 to 2019 for the 27 countries that make up the European Union at the time of the study. The data source was mainly open data from the official Eurostat website-Eurostat database (2021). Missing data for specific periods for some countries have been supplemented with relevant data from other sources - the World Data Atlas (2021). Note an important point: data 
from other sources were considered only when there was a coincidence of other relevant (in the series) already available data from Eurostat. Thus, we draw your attention to the fact that the data in various sources may not coincide due to their possible unreliability of the use of different methods for calculating the Gini coefficient itself.

To achieve the goal of the study, we took six countries as a sample. For the classification of countries, grouping data was used - the division of the considered set of data into homogeneous ones according to the studied characteristics. The sample was created based on the values of the standard deviation of the sample. To do this, we have determined a variation interval series with equal intervals according to the following algorithm, based on the Sturges formula (Feshchur, 2003):

1. Determination of the number of intervals by the formula:

$$
m=1+3,332 \lg n \text {, }
$$

where $\mathrm{n}$ is the number of elements in the population.

2. Determination of the width (step) of the interval by the formula:

$$
h=\frac{x_{\max }-x_{\min }}{m},
$$

where $x_{\max }, x_{\min }$ - respectively, the largest and the smallest value of the feature.

3. Plotting intervals for forming groups:

\begin{tabular}{lc} 
Step & Factor attribute $x_{i}$ \\
\hline 1. & {$\left[x_{\min } ; x_{\min }+h\right)$} \\
\hline 2. & {$\left[x_{\min }+h ; x_{\min }+2 h\right)$} \\
\hline 3. & {$\left[x_{\min }+2 h ; x_{\min }+3 h\right)$} \\
\hline$\ldots$ & $\ldots$ \\
\hline $\mathrm{N}$ & {$\left[x_{\max }-h ; x_{\max }\right]$}
\end{tabular}

One country was selected based on the median's criterion and the sample's standard deviation in each group. When the group contained an even number of countries, the country was established, which corresponded to the sample's standard deviation preceding the median. Thus, we formed a list of countries for further research. Since we took the time series of unstable values in the study field, the FORECAST ETS function (Excel for Microsoft 365) was used to determine the trend and calculate the Gini coefficient's predicted values. Calculates or predicts a future value based on existing (historical) values using the AAA version of the Exponential Smoothing (ETS) algorithm. The predicted value is a continuation of the historical values in the specified target date, which should be a continuation of the timeline.

\section{RESULTS}

In our analysis of the Gini coefficient from 2005 to 2019 (Table 1), we found indicator's value demonstrates an even distribution of income (not exceeding 40\%) in all countries of the European Union, except Bulgaria. Where the value of the coefficient exceeded the threshold value in 2019 (40.8\%), and this is the maximum value among all available for analysis. Following the method 
described above, we took the number of elements in the population $n=27$. According to formula (1), we obtained a value for the number of intervals $m=5.769$. That is, the list of 27 countries was divided into six groups.

Following formula (2), the step width of the interval was $h=0.410$. Next, we formed intervals to highlight groups of countries (table 2). According to the sample's median standard deviation criterion, one country was selected in each group. When the group contained an even number of countries, the country was selected, which corresponded to the standard deviation of the sample preceding the median. Thus, a list of countries for further research was formed: Italy, Spain, Germany, Slovakia, Hungary, Bulgaria.

We consider it necessary to supplement the analysis of the Gini coefficient dynamics with an emphasis on its maximum and minimum values during the study period relative to the values of 2008 and 2009 - the period of the financial crisis. Interestingly, the Gini coefficient values give the different amplitude of fluctuations (Table 3) - for Italy and Spain, the increase in the coefficient value is within 9\%, and for Bulgaria - more than 30\%. Simultaneously, in Slovakia and Hungary, there is a decrease in amplitude during 2005-2019 by more than 34 and 38\%, respectively. The analysis of the Gini coefficient values' reaction to the factors of the financial crisis of 2008-2009, complementing the study of the ratio S80/S20 disposable income quintile share reveal a decrease in Italy's studied indicator to $31.2 \%$ in the 2008 crisis year compared to the value before the crisis (32\%) with an increased S80/S20 ratio from 5.2 to 5.3 (table 4). In Spain, on the contrary, the indicator reaches its minimum value precisely in the pre-crisis year (with $S 80 / S 20=5.4$ ). During the crisis, the value of the coefficient increases by $1 \mathrm{pp}$, and this trend continues until 2014, when the maximum is reached $(34.7 \%$ at $\mathrm{S} 80 / \mathrm{S} 20=6.6)$. For Germany, the maximum and minimum values were recorded practically at the extreme points of our time series - in $2005(31.1 \%)$ and in 2018 (26.1\%), respectively (information on S80/S20 specifically for these periods in the considered database, was absent). A similar situation in the dynamics of the Gini coefficient is observed for Bulgaria. For Slovakia, the case is the opposite: the maximum (28.1\%) was recorded in 2006, and in the first year of the crisis, the value of the coefficient increased by $4.4 \mathrm{pp}$, the minimum was reached in 2018, and the difference in values is 9.2 pp with a slight difference S80/S20 - 3.6 in 2006 and 3.5 in 2018 with a maximum of 4.0 in the crisis of 2009. Finally, the Gini coefficient's most considerable fluctuation is observed in Hungary's indicators for - a decrease of $9.2 \mathrm{pp}$, which is $-38.17 \%$. 
完

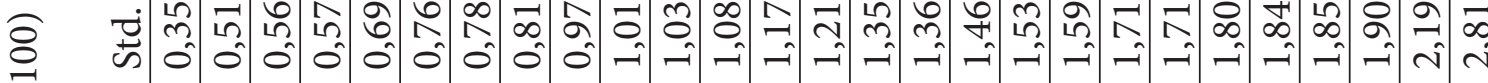

$\stackrel{0}{\circ}$

官论

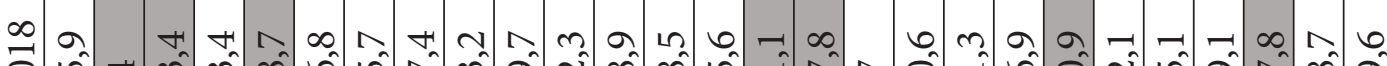
О्र

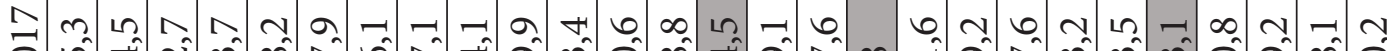

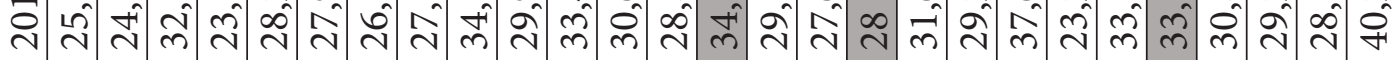

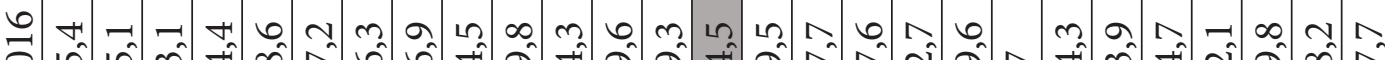

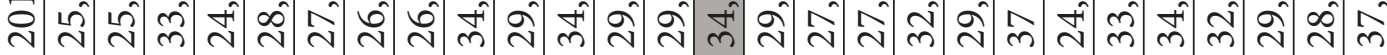

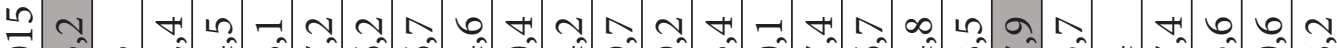

¿ํ)

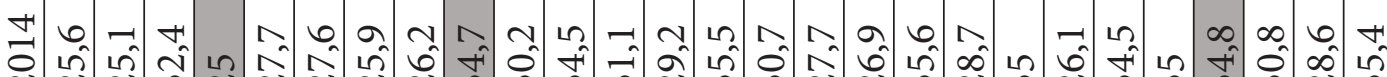
ত્ર

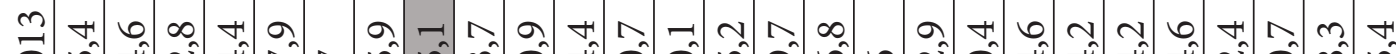

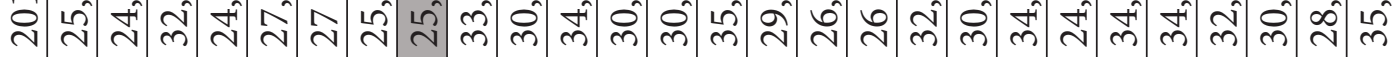

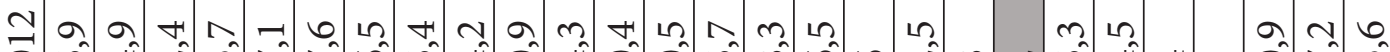

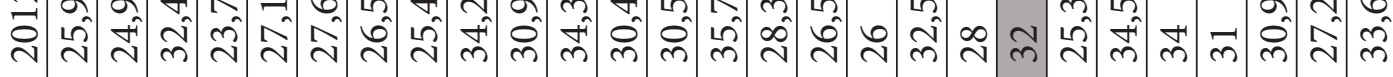

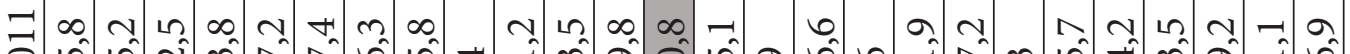

D)

을

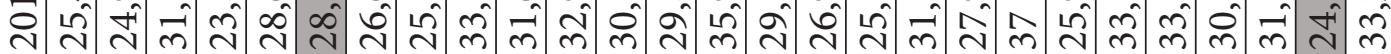

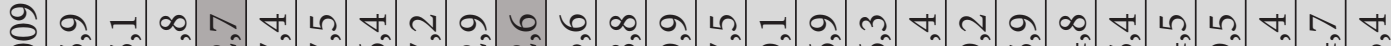
त्र

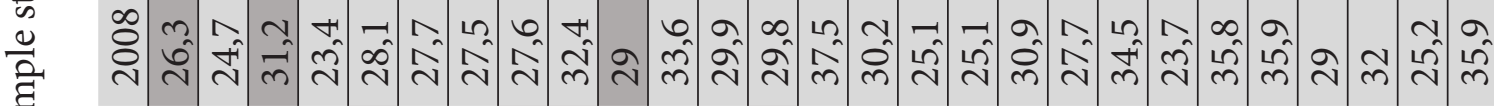

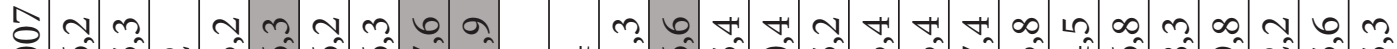

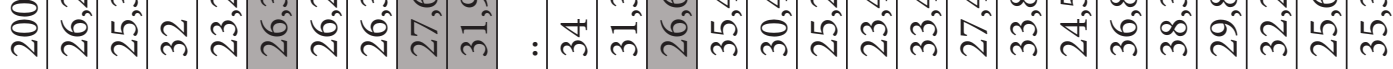

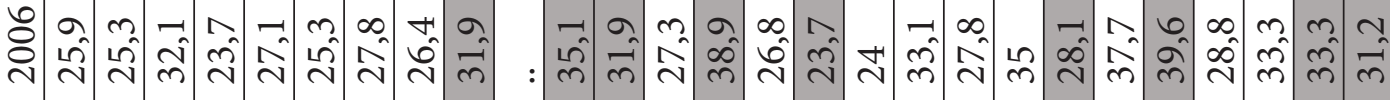

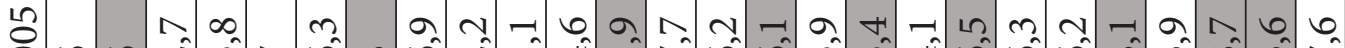

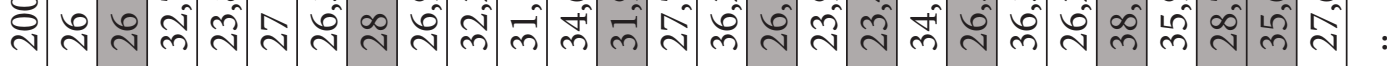

$\frac{\text { के }}{\frac{\pi}{2}}$

ב-1

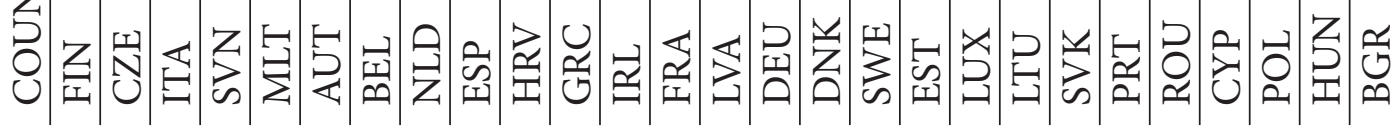


Table 2. Formation of the shortlist countries

\begin{tabular}{lllll} 
Interval & Interval start & End of interval & Median & Country \\
\hline 1 & 0,354 & 0,765 & 0,570 & ITA \\
\hline 2 & 0,765 & 1,175 & 0,994 & ESP \\
\hline 3 & 1,175 & 1,585 & 1,364 & DEU \\
\hline 4 & 1,585 & 1,996 & 1,759 & SVK \\
\hline 5 & 1,996 & 2,406 &.. & HUN \\
\hline 6 & 2,406 & 2,817 &.. & BGR
\end{tabular}

Source: Author's calculation

Table 3. Extremes of the Gini coefficient values in the shortlist countries

\begin{tabular}{llll} 
Country & Maximum, $\%$ & Minimum, $\%$ & Rate of increase, $\%$ \\
\hline ITA & 33,4 & 31,2 & $+7,05$ \\
\hline ESP & 34,7 & 31,9 & $+8,78$ \\
\hline DEU & 31,1 & 26,1 & $+19,16$ \\
\hline SVK & 28,1 & 20,9 & $-34,45$ \\
\hline HUN & 33,3 & 24,1 & $-38,17$ \\
\hline BGR & 40,8 & 31,2 & $+30,77$
\end{tabular}

Source: Author's calculation

Table 4. S80/S20 disposable income quintile share for the shortlist countries

\begin{tabular}{llllllllllllllll} 
Countries & 2005 & 2006 & 2007 & 2008 & 2009 & 2010 & 2011 & 2012 & 2013 & 2014 & 2015 & 2016 & 2017 & 2018 & 2019 \\
\hline ITA & 5,5 & 5,5 & 5,2 & 5,3 & 5,3 & 5,8 & 5,7 & 5,9 & 5,8 & 5,9 & 6,3 & 5,9 & 6,1 &.. &.. \\
\hline ESP &.. &.. & 5,4 & 5,7 & 6 & 6,1 & 6,3 & 6,1 & 6,6 & 6,6 & 6,5 & 6,5 & 6 & 5,9 &.. \\
\hline DEU &.. &.. &.. & 4,3 & 4,3 & 4,3 & 4,4 & 4,3 & 4,4 & 4,4 & 4,5 & 4,6 & 4,5 &.. &.. \\
\hline SVK & 4,2 & 3,6 & 3,6 & 3,7 & 4 & 3,9 & 3,9 & 3,7 & 4,1 & 3,7 & 3,7 & 3,7 & 3,2 & 3,5 &.. \\
\hline HUN &.. & 3,8 & 3,7 & 3,5 & 3,4 & 3,9 & 3,9 & 4,2 & 4,3 & 4,3 & 4,3 & 4,3 & 4,4 &.. &.. \\
\hline BGR &.. & 7,1 & 6,9 & 5,8 & 5,9 & 5,8 & 6,3 & 6,6 & 6,7 & 7,1 & 7,7 & 8,3 & 7,7 & 8,1 &..
\end{tabular}

Source: OECD Statistical Database (2021)

These tables show different ranges of fluctuations in the S80/S20 ratio for the countries under consideration in the period from 2005 to 2018:

- for Italy $5.2 \leq \mathrm{S} 80$ / S20 $\leq 6.3$.

- for Spain $5.4 \leq$ S 80 / S20 $\leq 6.6$.

- for Germany $4.3 \leq \mathrm{S} 80 / \mathrm{S} 20 \leq 4.6$.

- for Slovakia $3.2 \leq \mathrm{S} 80 / \mathrm{S} 20 \leq 4.2$.

- for Hungary $3.4 \leq \mathrm{S} 80 / \mathrm{S} 20 \leq 4.4$.

- for Bulgaria $5.9 \leq \mathrm{S} 80 / \mathrm{S} 20 \leq 8.3$.

As we can see, the maximum amplitude of the disposable income quintile share fluctuations is typical for Bulgaria, and the minimum for Germany. We consider it necessary to further pay attention to the study of these countries in distributing society's income. The calculation of the correlation coefficient for the Gini coefficient and the S80/S20 ratio gave the following results: its value for five countries is in the range from 0.20 to 0.66, and for Spain - 0.86 (please, see table 5). 
Table 5. Correlation coefficients for the Gini coefficients and the S80/S20 ratios for the shortlist countries

\begin{tabular}{lllllll} 
Countries & ITA & ESP & DEU & SVK & HUN & BGR \\
\hline $\begin{array}{l}\text { Correlation } \\
\text { coefficients }\end{array}$ & 0,564532 & 0,865265 & 0,196429 & 0,382344 & 0,410166 & 0,658433
\end{tabular}

Source: Author's calculation

We are using Excel FORECAST.ETS function to define the predicted Gini coefficient values and trendline for the three periods. Note that for 2020 the situation has already developed. We are only waiting for the Gini coefficient results for the last year to appear in the available databases to compare with our forecast. The forecast starts in 2019 since this period's values finish our data taken for research (Table 1). The results of calculating the predicted values and their graphical interpretation are presented below. We took a 95\% confidence interval for trend plotting. (Tables 6-11 and Figures 1-6).

Table 6. Predicted values of the Gini coefficient for Italy

\begin{tabular}{|c|c|c|c|c|}
\hline Periods & Gini coefficient & Forecast (ITA) & $\begin{array}{l}\text { Lower Confidence } \\
\text { Bound }\end{array}$ & $\begin{array}{l}\text { Upper Confidence } \\
\text { Bound }\end{array}$ \\
\hline 2019 & 32,8 & 32,8 & 32,80 & 32,80 \\
\hline 2020 & & 33,01837622 & 32,08 & 33,95 \\
\hline 2021 & & 33,09967338 & 31,93 & 34,27 \\
\hline 2022 & & 33,18097054 & 31,81 & 34,55 \\
\hline
\end{tabular}

Figure 1. The graphical interpretation of forecast the Gini coefficient for Italy

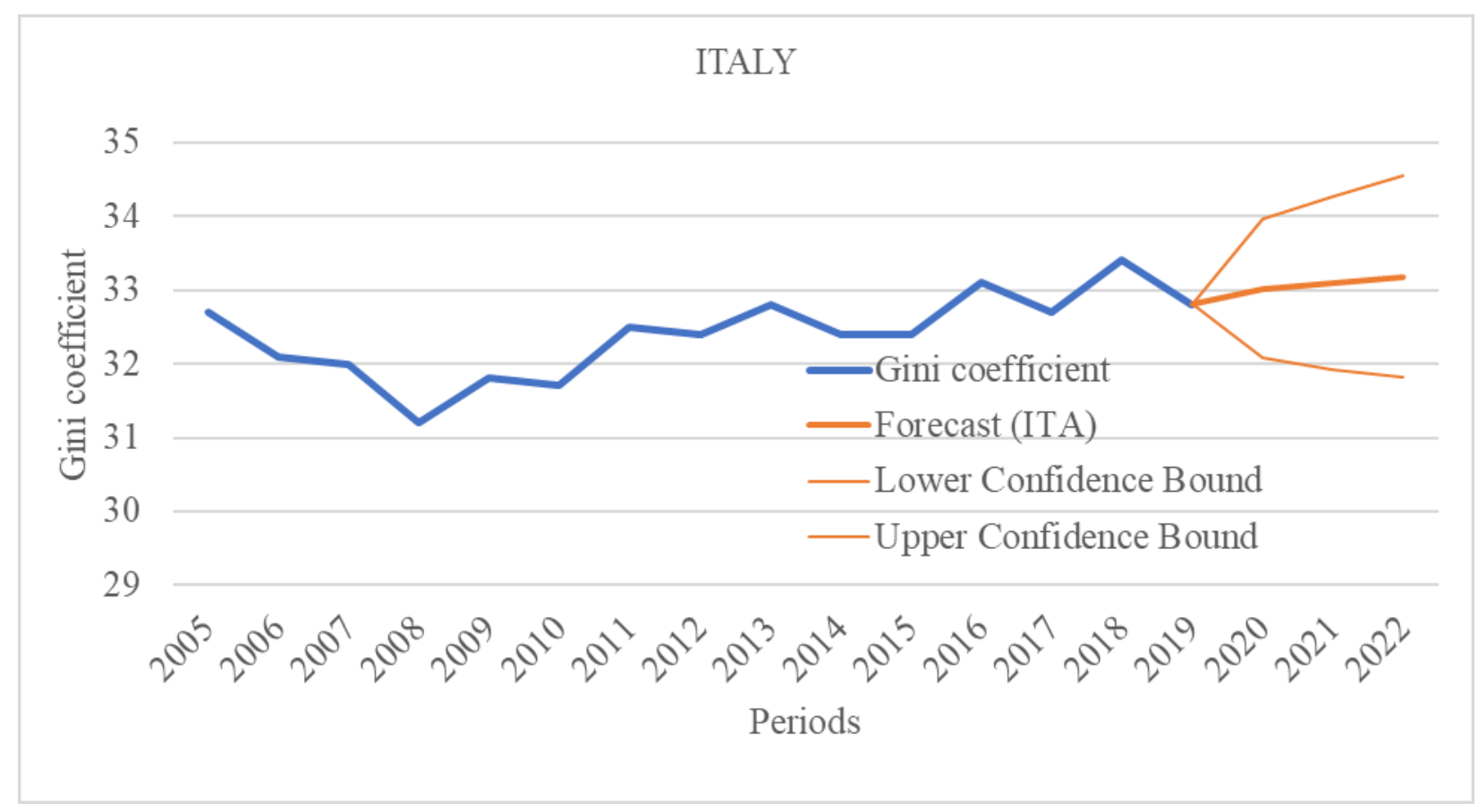

Source: Author's calculation 
Table 7. Predicted values of the Gini coefficient for Spain

\begin{tabular}{|c|c|c|c|c|}
\hline Periods & $\begin{array}{l}\text { Gini } \\
\text { coefficient }\end{array}$ & Forecast & $\begin{array}{l}\text { Lower Confidence } \\
\text { Bound }\end{array}$ & $\begin{array}{l}\text { Upper Confidence } \\
\text { Bound }\end{array}$ \\
\hline 2019 & 33 & 33 & 33,00 & 33,00 \\
\hline 2020 & & 33,14285714 & 32,08 & 34,21 \\
\hline 2021 & & 33,28571429 & 32,10 & 34,47 \\
\hline 2022 & & 33,42857143 & 32,13 & 34,73 \\
\hline
\end{tabular}

Figure 2. The graphical interpretation of forecast the Gini coefficient for Spain

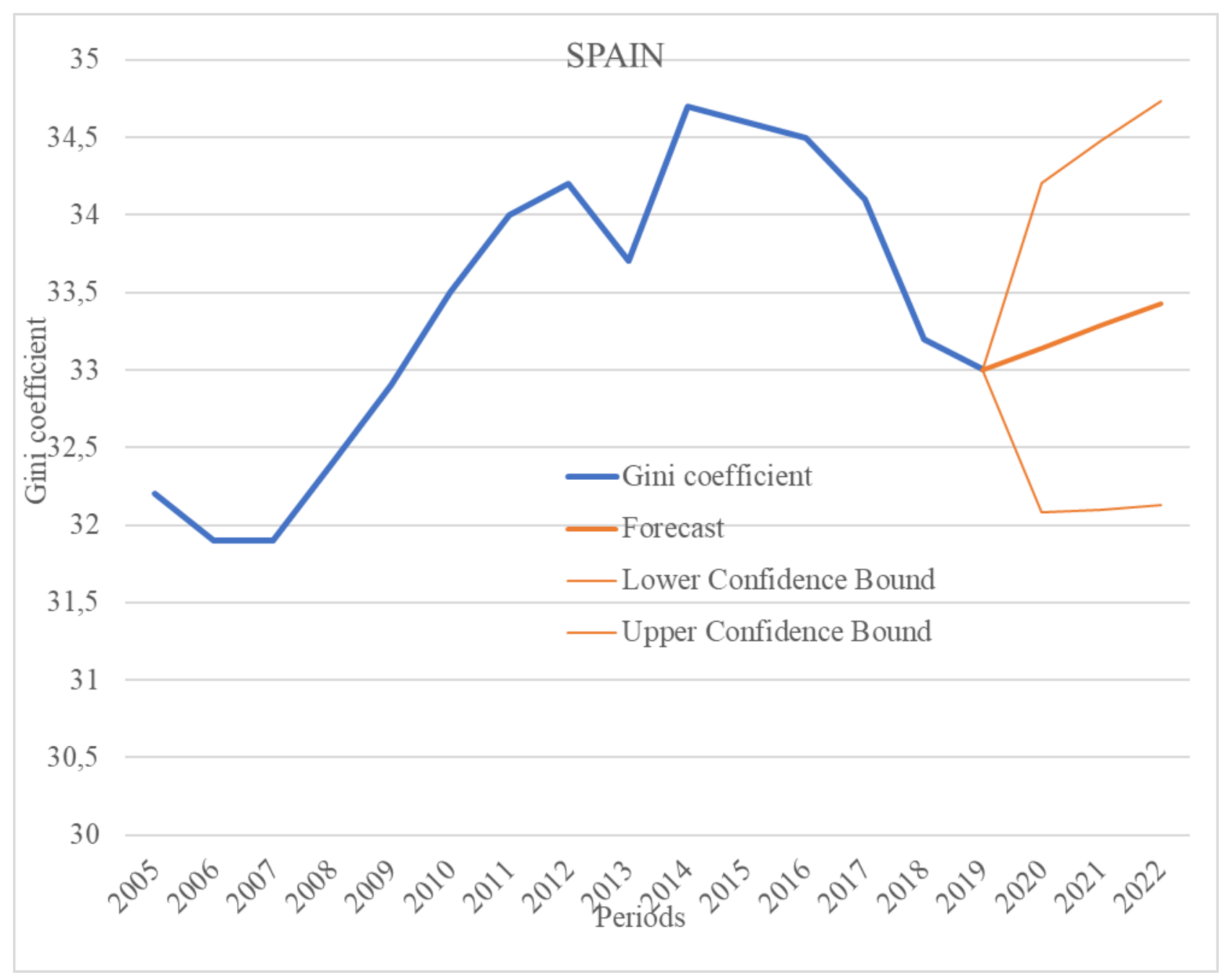

Table 8. Predicted values of the Gini coefficient for Germany

\begin{tabular}{lllll} 
Periods & $\begin{array}{l}\text { Gini } \\
\text { coefficient }\end{array}$ & Forecast & $\begin{array}{l}\text { Lower Confidence } \\
\text { Bound }\end{array}$ & $\begin{array}{l}\text { Upper Confidence } \\
\text { Bound }\end{array}$ \\
\hline 2019 & 29,7 & 29,7 & 29,70 & 29,70 \\
\hline 2020 & & 30,01347503 & 27,54 & 32,49 \\
\hline 2021 & 30,18706115 & 26,85 & 33,52 \\
\hline 2022 & 30,36064727 & 26,35 & 34,37
\end{tabular}

Source: Author's calculation 
Figure 3. The graphical interpretation of forecast the Gini coefficient for Germany

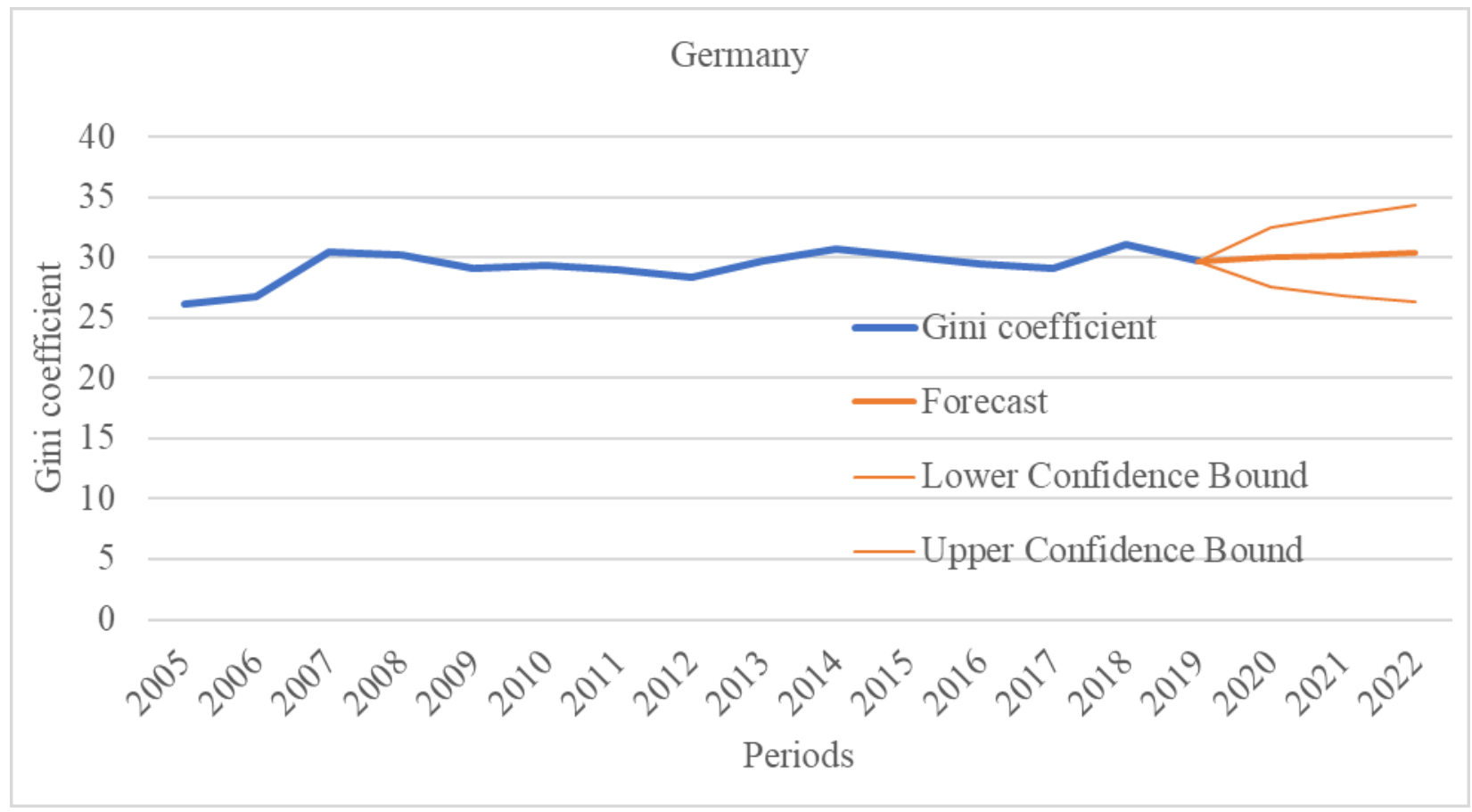

Source: Author's calculation

Table 9. Predicted values of the Gini coefficient for Slovakia

Periods Gini coefficient Forecast Lower Confidence Upper Confidence

\begin{tabular}{|c|c|c|c|c|}
\hline & & & Bound & Bound \\
\hline 2019 & 22,8 & 22,8 & 22,80 & 22,80 \\
\hline 2020 & & 22,20130967 & 19,81 & 24,60 \\
\hline 2021 & & 21,93617828 & 19,54 & 24,33 \\
\hline 2022 & & 21,67104688 & 19,28 & 24,06 \\
\hline
\end{tabular}

Source: Author's calculation

Figure 4. The graphical interpretation of forecast the Gini coefficient for Slovakia

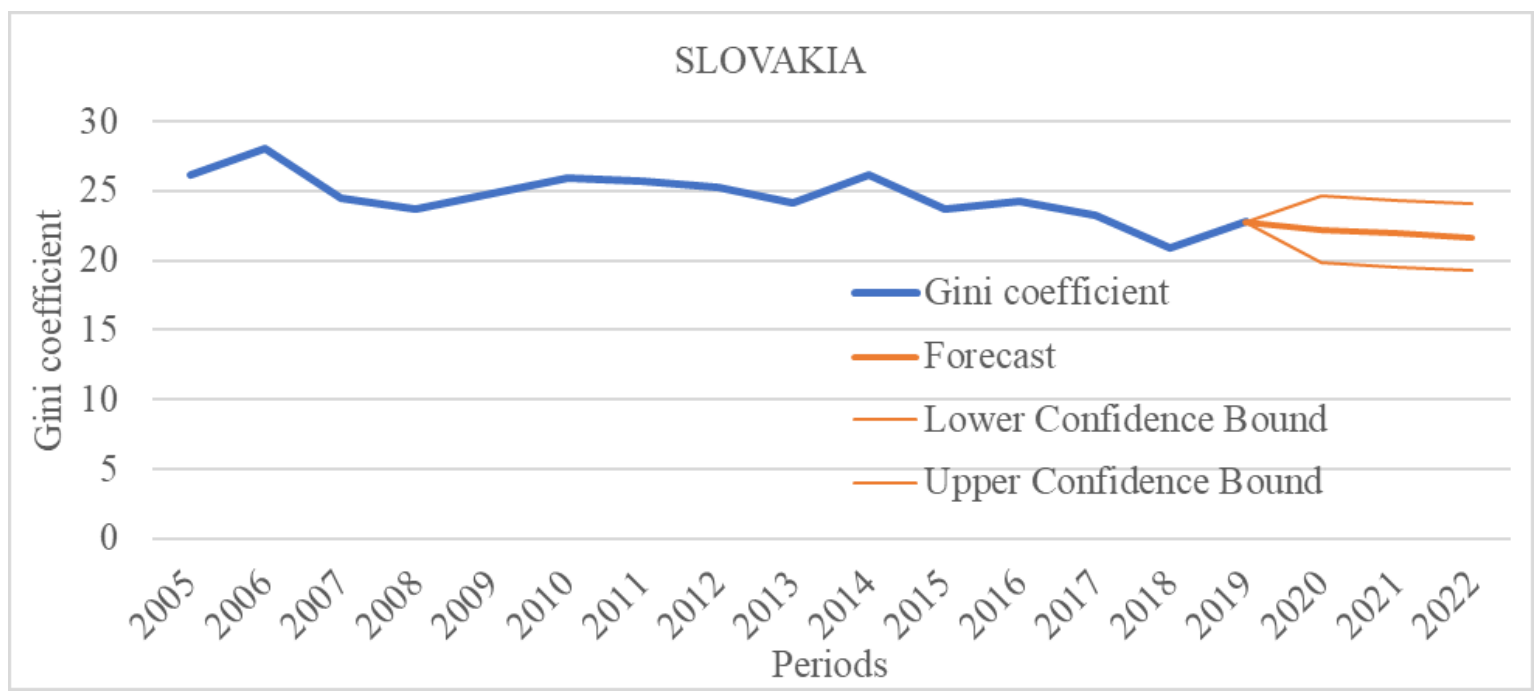

Source: Author's calculation 
Table 10. Predicted values of the Gini coefficient for Hungary

\begin{tabular}{lllll} 
Periods & $\begin{array}{l}\text { Gini } \\
\text { coefficient }\end{array}$ & Forecast & $\begin{array}{l}\text { Lower Confidence } \\
\text { Bound }\end{array}$ & $\begin{array}{l}\text { Upper Confidence } \\
\text { Bound }\end{array}$ \\
\hline 2019 & 28 & 28 & 28,00 & 28,00 \\
\hline 2020 & & 28,61505522 & 24,34 & 32,89 \\
\hline 2021 & & 28,67996771 & 24,41 & 32,95 \\
\hline 2022 & 28,74488019 & 24,47 & 33,02
\end{tabular}

Source: Author's calculation

Figure 5. The graphical interpretation of forecast the Gini coefficient for Hungary

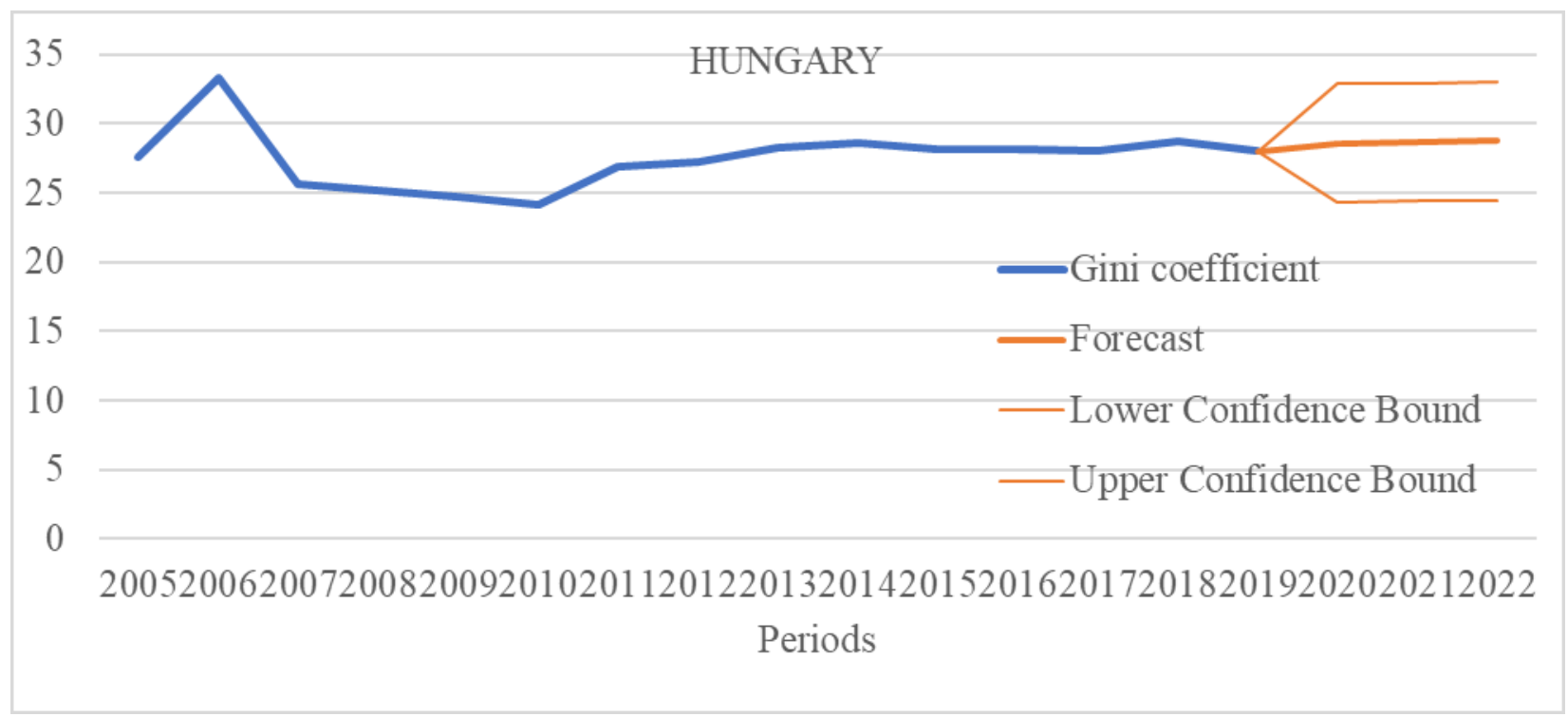

Source: Author's calculation

Table 11. Predicted values of the Gini coefficient for Bulgaria

\begin{tabular}{lllll} 
Periods & $\begin{array}{l}\text { Gini } \\
\text { coefficient }\end{array}$ & Forecast & $\begin{array}{l}\text { Lower Confidence } \\
\text { Bound }\end{array}$ & $\begin{array}{l}\text { Upper } \\
\text { Confidence } \\
\text { Bound }\end{array}$ \\
\hline 2019 & 40,8 & 40,8 & 40,80 & 40,80 \\
\hline 2020 & & 40,16218628 & 37,06 & 43,26 \\
\hline 2021 & 40,74805038 & 37,63 & 43,86 \\
\hline 2022 & 41,33391449 & 38,20 & 44,47
\end{tabular}

Source: Author's calculation

From the "Forecast" columns in tables 6-11 and the corresponding middle lines in Figures 1-6, we can see a steady decline in income equity for four of the six countries. Only for Bulgaria, we can expect insignificant fluctuations, but with an increased value of the Gini coefficient in 2023 (41.3) compared to 2019 (40.8). For Slovakia, on the contrary, after fluctuations during the forecast period, we can expect a decrease in the coefficient Gini in 2023 (21.67) compared to 2019 (22.8). 
Figure 6. The graphical interpretation of forecast the Gini coefficient for Bulgaria

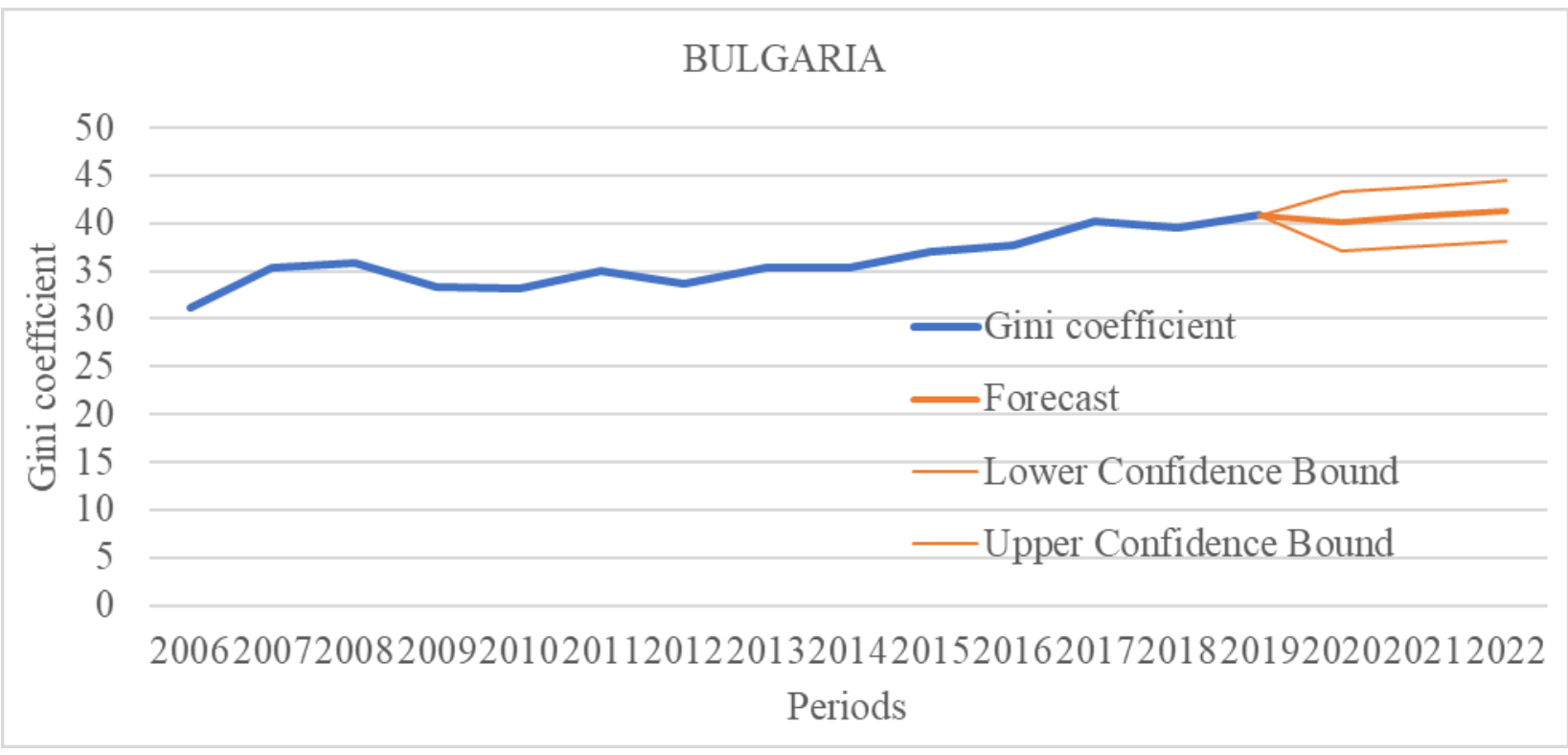

Source: Author's calculation

\section{DISCUSSION}

This study aims to study the Gini coefficient's behavior from 2005 to 2019 and predict its values for three subsequent periods. This time interval includes the financial crisis of 2008-2009. This made it possible to analyze whether there is a commonality for all countries' specific reactions to the recession factors. Our analysis was complicated because the Eurostat statistical database for the Gini coefficient contained incomplete information since the list of 27 European Union countries relevant at the time of the study was not formed at one time. It is known that this process was extended over time. Some countries during this period became members of the EU. Others, on the contrary, left it. We had to turn to other scattered sources, which also introduced problems informing the database for research. After all, it is known that there are various algorithms for calculating the Gini coefficient, allowing the use of different levels of income (before or after taxation, with or without transfers, and other nuances). We decided to consider the indicator's values from other sources only if Eurostat's existing values for different periods coincided. As a result, several cells in Table 1 related to Croatia $(2006,2007)$ and Bulgaria (2005) were left blank. We also assume that we came across inaccurate information in the event of a contradiction with the available Eurostat data. Since the Eurostat database uses a scale from 0 to 100, that is, the Gini coefficient is estimated as a percentage, our entire study is based on the use of this measurement scale too.

To concentrate on-point the analysis of the Gini coefficient values (extremes are the minimum and maximum values during the entire study period) and the reaction of these values to the crisis period, we decided to form a shortlist of countries represent our general list. As a criterion for classification, we took the standard deviation of the sample. In table 1, the list of countries is presented in a sorted form for this very indicator. Choosing a grouping method was also not easy. Depending on the data analyzed, statistical theory offers many different options for grouping. This procedure's simplicity and clarity were essential for us, so we stopped at the division of the considered set of data into homogeneous ones according to the studied characteristics, based on the Sturges formula. In our case, we used the sample standard deviation as such a feature, as noted above. As a result, a shortlist of countries for in-depth analysis was determined - Italy, Spain, Germany, Slovakia, Hungary, and Bulgaria. 
In Table 1, we highlighted the values of the highs and lows for all 27 countries, but for all countries, we did this only to demonstrate that the spread of these values is not related to the crisis period (two columns are highlighted in grey). There is no synchronicity in the Gini coefficient reaching extremes. We have provided more detailed comments on the extremes for the short-listed countries. We supplemented the analysis of extreme values with an estimate of the rate of growth of the indicator (Table 3), which made it possible to feel the scope and direction of change in the indicator for each of the six countries separately and compare countries with each other. A point to be noted is that the "-" sign indicates that the sequence of minimum and maximum values along the period under study also does not have a general rule and is not associated with the crisis period. We concluded the absence of general trends in changes in the inequality of income distribution in society as a reaction to the factors of the financial crisis. We were interested in introducing the study field S80/S20 disposable income quintile share for shortlisted countries. It shows the ratio of the $20 \%$ of people with the highest household income in total household income to $20 \%$ of persons with the lowest household income in total household income. Analysis of the S80/S20 ratio made it possible to single out Germany and Bulgaria as the countries with the smallest and largest ratios, respectively. We have already planned to delve deeper into studying the policies and instruments used by government regulation to reduce inequality in these two countries for comparative analysis. Calculation of the correlation coefficient for the Gini coefficient values and the S80/S20 ratio showed a weak strength of the statistical relationship. Only for Spain, the value reaches 0.86 , which is not enough for generalization.

Concerning forecasting the values of the Gini coefficient for future periods, we limited the calculation to three periods, including 2020. We will soon be able to check the accuracy of our forecast by comparing our values with the actual ones in the available sources soon. Realizing that the world economy, including the economies of the EU countries, is still under the influence of the Covid-19 pandemic and having information about the third wave of the virus, we decided not to extend the forecast period. As we demonstrated in Tables 6-11 and Figures 1-6, the shortlisted countries show predominantly increases in inequality in income distribution, as evidenced by an increase in the Gini coefficient for five countries out of six. And only for Slovenia, the statistical forecast gave a decrease in the values of the coefficient, that is, the dynamics towards greater equality in the distribution of income. The extension of the general forecasting period is inappropriate due to the impact of the crisis provoked by the Covid-19 pandemic. The impact of the pandemic causes large errors in longer projections. 


\section{CONCLUSION}

We studied the Gini coefficient's behavior over a reasonably long time - from 2005 to 2019 and predicted its values for three subsequent periods. This time interval was interesting for the authors because it included the period of the financial crisis of 2008-2009. Our first objective, in which we highlight the trends in income distribution inequality during the Global Financial crisis of 2008-2009, showed the absence of general trends in income distribution inequality in society due to the financial crisis. The second objective was an analysis of the S80/S20 ratio, calculation of the correlation coefficient for the Gini coefficient values, and the S80/S20 rate showed a weak strength of the statistical relationship. Only for Spain, the value reaches 0.86 , which, of course, is not enough for generalization. In the third objective, we attempt to predict the Gini coefficient's future value for three future periods. The results of the shortlisted countries show predominant increases in income distribution inequality, as evidenced by the Gini coefficient's rise for five countries out of six. And only for Slovenia, the statistical forecast gave a decrease in the coefficient values, that is, towards greater equality in the distribution of income. However, the study has some limitations. We have considered only the Gini coefficient; researchers can include other measures of income inequalities. We do not have a multivariate model, so for future studies, other measures of income inequality can be included. There is also scope for an in-depth analysis of the future of three countries - Germany, Bulgaria, Slovakia. Additional research could establish links between these countries' monetary policies and the values of the Gini coefficient. Scholars can also extend the study to compare the EU countries' income inequality with other trade blocs like BRICS and G-20 and other European countries. 


\section{REFERENCES}

Anand, P. S.(2008). What Do We Know about Global Income Inequality?, in: Journal of Economic Literature, Vol. 46, No. 1, pp. 57-94

Alesina, A., \& La Ferrara, E. (2002). Who trusts others? Journal of Public Economics, 85(2), 207-234.

Alfani G. (2019) Wealth and Income Inequality in the Long Run of History. In: Diebolt C., Haupert M. (eds) Handbook of Cliometrics. Springer, Cham. https://doi.org/10.1007/978-3-030-00181-0_29

Atkinson AB, Morelli S (2013) A Chartbook of Economic Inequality. http://ineteconomics.org/ research_note/chartbookeconomic-inequality-25-countries-1911-2010

Brandolini,A. (2007). Measurement of Income Distribution in Supranational Entities: The Case of the European Union, Temi di discussione, No. 623, Bank of Italy.

Barro, R, J Ursua and J Weng (2020), "Coronavirus meets the Great Influenza Pandemic", VoxEU. org, 20 March.

Blanchet, T, L Chancel and A Gethin (2019), "How unequal is Europe? Evidence from distributional national accounts", WID.world Working Paper 2019/6.

Castells-Quintana, D. and Royuela, V. (2014a) "Agglomeration, Inequality and Economic Growth" Annals of Regional Science, 52, 343-366.

Castells-Quintana, D and Royuela, V. (2014b) “Tracking positive and negative effects of inequality on long-run growth”, IREA Working Paper 2014/01. Available at http://www.ub.edu/irea/working_papers/2014/201401.pdf

Checchi, D. (2003). Inequality in Incomes and Access to Education. A Cross-country Analysis (1960-95). Labour, 17(2), 153- 201.

Checchi D., V.Peragine and Serlenga, L. (2010). Fair and Unfair Income Inequalities in Europe. IZA Discussion Paper No. 5025/2010

Checchi, D., Peragine, V. and Serlenga, L. (2016), "Inequality of Opportunity in Europe: Is There a Role for Institutions?" Inequality: Causes and Consequences (Research in Labor Economics, Vol. 43), Emerald Group Publishing Limited, Bingley, pp. 1-44. https://doi.org/10.1108/S0147-912120160000043008

Credit Suisse Research Institute (CSRI). 2017. Global Wealth Report. Available at: https://www.creditsuisse.com/corporate/en/research/research-institute/global-wealthreport.html

Dauderstadi, M. (2008). Ungleichheit und sozialer Ausgleich in der erweiterten Europäischen Union, in: Wirtschaftsdienst, Vol. 88, No. 4, pp. 261-269.

Dorwick, S, Akmal, M.A. (2005). Contradictory Trends in Global Income Inequality: a Tale of Two Biases, in: Review of Income and Wealth, Vol. 51, No. 2, June 2005.

Eliazar II, Sokolov IM (2012) Measuring statistical evenness: a panoramic overview. Phys A 391:1323-1353

Eliazar II (2018) A tour of inequality. Ann Phys 389:306-332

Eurostat Database (2021). Retrieved from: https:/ec.europa.eu/eurostat/web/main/data/database [Online Resource].

Excel for Microsoft 365. Retrieved from: https://support.microsoft.com/en-us/office/forecast-etsfunction-15389b8b-677e-4fbd-bd95-21d464333f41) [Online Resource].

Fajnzylber, P., Lederman, D., \& Norman, L. (2002a). What causes violent crime? European Economic Review, 46(7), 1323- 1357.

Fajnzylber, P., Lederman, D., \& Norman, L. (2002b). Inequality and Violent Crime. Journal of Law and Economics, 45(1), 1- 40.

Feshchur, R., Barvinskiy, A., \& Kichor, V. (2003) Statistika: teoretichni zasadi i prikladni aspekti [Statistics: theoretical principles and applied aspects]. Intelekt-Zakhid. Lviv. P.21. 
Ferrer-i-Carbonell, A. (2005). Income and Well-being: An Empirical Analysis of the Comparison Income Effect, Journal of Public Economics, 895-6, 997-1019.

Franzini, M. (2009). Why Europe Needs a Policy on Inequality, in: Intereconomics, Vol. 44, No. 6.

Frey, B. S., Stutzer,A. (2002). Happiness and Economics. How the Economy and Institutions Affect Well-being, Princeton University Press, Princeton, New Jersey.

Gastwirth, J. L. (1972), "Robust Estimation of the Lorenz Curve and Gini index", Review of Economics and Statistics, 54, 306-316.

Giorgi, G. M. (1990), "Bibliographic Portrait of the Gini Concentration Ratio", Metron, 48, 183-221.

Gini C (2005) On the measurement of concentration and variability of characters. De Santis F (trans) Metron 63:3-38.

Gini C (1912) Variabilità e mutabilità: contributo allo studio delle distribuzioni e delle relazioni statistiche. Tipografia di Paolo Cuppini, Bologna.

Global Risks Report 2021 - Reports - World Economic Forum. Retrieved from: https://www.weforum.org/

Heathcote, Jonathan, Perri, Fabrizio, Violante, and Gianluca (2010a), "Inequality in times of crisis: lessons from the past and a first look at the current recession”, VOX, 2 February 2010.

Heathcote, Jonathan and Perri, Fabrizio and Violante, Gianluca (2010b), "Unequal we stand: an empirical analysis of economic inequality in the United States, 1967-2006", Review of Economic Dynamics, Vol. 13, issue 1,

Heiko, P., Volwahsen, M. (2017). Rising Income Inequality: Do Not Draw the Obvious Conclusions. Intereconomics. Volume 52, $2017 \cdot$ Number $2 \cdot$ pp. 111-118

Jordà, O (2005), "Estimation and inference of impulse responses by local projections", American Economic Review 95: 161-182.

Krugman, P. (2008) The return of depression economics and the crisis of 2008. Penguin. London

Krueger, Dirk et al. (2010), "Cross-sectional facts for macroeconomists", Review of Economic Dynamics, Vol. 13, issue 1.

Knack, S., \& Keefer, P. (1997). Does Social Capital Have an Economic Payoff? A Cross-Country Investigation. The Quarterly Journal of Economics, 112(4), 1251-1588.

Milanovic,B. (2002). True World Income Distribution, 1988 and 1993: First Calculation Based on Household Surveys Alone, in: Economic Journal, Vol. 112, No. 476, pp. 51-91 OECD (2021), Income inequality (indicator). doi: 10.1787/459aa7f1-en (Accessed on 06 March 2021)

Partridge, M. (2005) “Does income distribution affect US State economic growth?" Journal of Regional Science, 45(2), 363-394.

Perotti, R. (1993, June). Growth, Income Distribution and Democracy: What the Data Say. 1(2), 149-187.

Picketty, T. (2020). Capital and Ideology, The Belknap Press of Harvard University Press

Picketty, T. (2013). Capital in the Twenty-First Century, MA: Harvard Univheaersity Press.

Rajan, R. (2010) Fault Lines: How hidden fractures still threaten the world economy, Princeton University Press.

Rodriguez-Pose, A., Tselios, V. (2008) "Inequalities in income and education and regional economic growth in Western Europe”, Annals of Regional Science, 44, 349-375.

Sanfey, P., \& Teksoz, U. (2005). Does Transition Make You Happy? European Bank for Reconstruction and Development Working Paper No. 91.

Sala-i-Martin., X. (2006). The World Distribution of Income: Falling Poverty and Convergence, Period, in: Quarterly Journal of Economics, Vol. 121, No. 2, pp. 351-397

Schwarze, J., \& Harpfer, M. (2007). Are People Inequality Averse, and Do They Prefer Redistribution by the State? Evidence from German Longitudinal Data On Life Satisfaction. Journal of Socio-Economics, 36(2), 233-249. 
Senik, C. (2006). Ambition and Jealousy: Income Interactions in the "Old" Europe Versus the "New" Europe and the United States. IZA Discussion Paper No. 2083.

Solt, F. (2008). "Economic Inequality and Democratic Political Engagement", American Journal of Political Science, 52(1), 48-60.

Stiglitz, J. (2009) "The global crisis, social protection and jobs" International Labour Review, 148 (1-2),1-13.

Wilkinson, R., \& Pickett, K. (2009). The Spirit Level, Why More Equal Societies Almost Always Do Better. Allen Lane.

World Data Atlas (2021). Retrieved from: https://knoema.ru [Online Resource].

World Wealth and Income Database (WID). https://wid.world/data/ [Online Resource]. 